\title{
The effect of travel restrictions on the spread of the 2019 novel coronavirus (COVID-19) outbreak
}

\author{
Matteo Chinazzi ${ }^{1}$, Jessica T. Davis ${ }^{1}$, Marco Ajelli ${ }^{2}$, Corrado Gioannini ${ }^{3}$, Maria Litvinova ${ }^{3}$, Stefano Merler $^{2}$, Ana \\ Pastore y Piontti' ${ }^{1}$, Kunpeng $\mathrm{Mu}^{1}$, Luca Rossi ${ }^{3}$, Kaiyuan Sun ${ }^{4}$, Cécile Viboud ${ }^{4}$, Xinyue Xiong ${ }^{1}$, Hongjie Yu$^{5}$, M. \\ Elizabeth Halloran ${ }^{6,7}$, Ira M. Longini Jr. ${ }^{8 *}$, Alessandro Vespignani ${ }^{1,3 *}$
}

${ }^{1}$ Laboratory for the Modeling of Biological and Socio-technical Systems, Northeastern University, Boston, MA, USA. ${ }^{2 B}$ Bruno Kessler Foundation, Trento, Italy. ${ }^{3}$ ISI Foundation, Turin, Italy. ${ }^{4}$ Fogarty International Center, NIH, USA. ${ }^{5}$ School of Public Health, Fudan University, Key Laboratory of Public Health Safety, Ministry of Education, Shanghai, China. ${ }^{6}$ Fred Hutchinson Cancer Research Center, Seattle, WA, USA. ${ }^{7}$ Department of Biostatistics, University of Washington, Seattle, WA, USA. ${ }^{8}$ Department of Biostatistics, College of Public Health and Health Professions, University of Florida, Gainesville, FL, USA.

*Corresponding author. Email: a.vespignani@northeastern.edu (A.V.); ilongini@ufl.edu (I.M.L.)

Motivated by the rapid spread of COVID-19 in Mainland China, we use a global metapopulation disease transmission model to project the impact of travel limitations on the national and international spread of the epidemic. The model is calibrated based on internationally reported cases, and shows that at the start of the travel ban from Wuhan on 23 January 2020, most Chinese cities had already received many infected travelers. The travel quarantine of Wuhan delayed the overall epidemic progression by only 3 to 5 days in Mainland China, but has a more marked effect at the international scale, where case importations were reduced by nearly $80 \%$ until mid February. Modeling results also indicate that sustained $90 \%$ travel restrictions to and from Mainland China only modestly affect the epidemic trajectory unless combined with a $50 \%$ or higher reduction of transmission in the community.

Starting in December 2019, Chinese health authorities have been closely monitoring a cluster of pneumonia cases in the city of Wuhan, in Hubei province. The pathogen causing the viral pneumonia among affected individuals is the new coronavirus SARS-CoV-2 (1). As of 3 March 2020, a total of 80,151 (2) cases have been detected and confirmed in Mainland China. Internationally, there are more than 10,566 additional cases detected and confirmed in 72 countries (3). In this work we model both the domestic and international spread of the novel coronavirus (COVID-19) epidemic. We estimate the effects of the travel ban implemented in Wuhan and the international travel restrictions adopted by several countries in early February, 2020.

To model the international spread of the COVID-19 outbreak we use the Global Epidemic and Mobility Model (GLEAM), an individual-based, stochastic, and spatial epidemic model (4-7). GLEAM uses a metapopulation network approach integrated with real-world data where the world is divided into sub-populations centered around major transportation hubs (usually airports). The subpopulations are connected by the flux of individuals traveling daily among them. The model includes over 3,200 sub-populations in roughly 200 different countries and territories. The airline transportation data consider daily origin-destination traffic flows from the Official Aviation Guide (OAG) and IATA databases (updated in 2019), while ground mobility flows are derived by the analysis and modeling of data collected from the statistics offices for 30 countries on 5 continents (5). Mobility variations in Mainland China were derived from Baidu Location-Based Services (LBS). Within each sub-population, the human-to-human transmission of COVID-19 is modeled using a compartmental representation of the disease where individuals can occupy one of the following states: Susceptible $(S)$, Latent $(L)$, Infectious $(I)$ and Removed $(R)$. Susceptible individuals can acquire the virus through contacts with individuals in the infectious compartment, and become latent, meaning they are infected but can not transmit the infection yet. Latent individuals progress to the infectious stage with a rate inversely proportional to the latent period (which we assume to have the same duration as the incubation period), and infectious individuals progress into the removed stage with a rate inversely proportional to the infectious period. The sum of the mean latent and infectious periods defines the generation time. Removed individuals represent those who can no longer infect others, meaning they were isolated, hospitalized, have recovered, or died.

The model generates an ensemble of possible epidemic scenarios described by the number of newly generated infections, times of disease arrival in each subpopulation, and the number of traveling infection carriers. We assume a starting date of the epidemic that falls between 11/15/2019 and $12 / 1 / 2019$, with 40 cases caused by zoonotic exposure (8-11). The transmission dynamic is calibrated by using an Approximate Bayesian Computation approach (12) to estimate the posterior distribution of the basic reproductive number $R_{0}$ by exploring the likelihood of importation of COVID-19 
infections to international locations (13). We assume that the overall global detection of imported cases can be as low as $40 \%(14,15)$. Data on importation of cases were obtained from currently available published line lists $(16,17)$.

We have performed a sensitivity analysis by considering different combinations of average latent and infectious periods, detection rates, initial conditions, and a generation time $\left(T_{\mathrm{g}}\right)$ ranging from 6 to 11 days based on plausible ranges from the SARS epidemic and recent analysis of COVID-19 data (16, 18-23). Details and sensitivity analysis on all parameters are reported in (12). In the following we report the results for generation time $T_{\mathrm{g}}=7.5$ days (20). The obtained posterior distribution provides an average reproductive number $R_{0}=2.57$ [90\% CI 2.37-2.78], and a doubling time measured at $T_{\mathrm{d}}=4.2$ days [90\% CI 3.8-4.7]. The obtained values are in the same range as previous analyses based on early COVID-19 data ( 9 , $20,24-26)$. Although the calibration obtained for different generation times provides different posterior distributions for $R_{0}$, in the early stages of the epidemic the prevalence of infections and case importations are determined by the epidemic growth rate and the obtained results (12) are consistent with those reported here.

\section{Wuhan travel ban}

On 22 January 2020, the projected median number of cases with no travel restrictions for Mainland China excluding Wuhan is 7,474 [90\% CI 3,529-16,142]. The overwhelming majority of cases are in Wuhan with a median number of 117,584 [90\% CI 62,468-199,581]. To analyze the effect of the travel ban from Wuhan, we implemented long-range travel restrictions beginning on 23 January (airport shut down). Furthermore, mobility limitations within Mainland China are modeled by using de-identified and aggregated domestic population movement data between Chinese provinces for February 2020 as derived from Baidu Location-Based Services (LBS) (12).

Initially, we assume no changes in the transmissibility and disease dynamics: i.e., the status quo scenario. The model output shows no noticeable differences in the epidemic trajectory of Wuhan, while it shows a delay of about 3 days occurring for other locations in Mainland China (see Fig. 1A). The overall reduction of cases in Mainland China excluding Wuhan is close to $10 \%$ by 31 January 2020 , with a relative reduction of cases across specific locations varying in a range from $1 \%$ to $58 \%$ (Fig. 2). With a doubling time of 4-5 days, this level of reduction corresponds to only a modest delay of the epidemic trajectory of 1 to 6 days in Mainland China. These results are in agreement with estimates resulting from the combination of epidemiological and human mobility data (27). The model indicates clearly that as of 23 January 2020, the epidemic was seeded in several locations across Mainland China. As an independent validation test, we show in Fig. 1B, the cumulative number of cases in Mainland China provinces through 1 February 2020, as reported from the official WHO situation report (28), and compare these results with model projections. The model projections are highly correlated with the observed data (Pearson's $r=0.74, P<0.00001$ ), although as expected we find that there are significantly fewer reported cases than projected (See Fig. 1B). If we assume that the number of reported cases in the WHO situation report and in the simulation are related through a simple binomial stochastic sampling process, we find that the median ascertainment rate of detecting an infected individual in Mainland China is equal to $24.4 \%$ [IQR: $12.7 \%, 35.8 \%$ ]. In other words, the modeling results suggest that in Mainland China only one out of four cases are detected and confirmed.

\section{Relative risk of case importation}

The model also allows us to estimate the number of case importations in international locations from Mainland China. In Fig. $1 \mathrm{C}$ we report the mean number of total international importation events in a fully status quo scenario compared to the presence of a travel ban. We find a $77 \%$ reduction in cases imported from Mainland China to other countries as a result of the Wuhan travel ban in early February. While the number of cases imported internationally initially shows a marked decrease, it picks up again in the following weeks with importation from locations in Mainland China. The model indicates that after the travel restrictions in Wuhan are implemented on 23 January, the top 5 ranked cities as the origin of international case importations are Shanghai, Beijing, Shenzhen, Guangzhou, and Kunming. Similarly, the model can rank countries across the world according to the relative risk of importing cases from Mainland China. More precisely, the relative risk is defined for each country $Y$ as the relative probability $P(Y)$ that a single infected individual travels from the areas affected by the epidemic to that specific destination $Y$. In other words, given the occurrence of one exported case, $P(Y)$ is the relative probability that the disease carrier will appear in location $Y$, with respect to any other possible location. This risk depends on the travel flow from cities in Mainland China to other countries and the disease prevalence in those cities. It is also worth noting that the traffic flows used in the model are origin-destination data that do not depend on traveling routes; i.e., a proxy for the actual mobility demand across cities. In Fig. 3 we provide a visualization of how each one of the top cities in Mainland China contribute to the relative risk of the top 20 countries at risk of importation for the dates before and after the travel ban in Wuhan was in effect. In particular, before the travel ban $\approx 86 \%$ of the internationally imported cases originated from Wuhan. After the travel ban, the top 10 contributors to the relative risk are needed to account for at least $\approx 80 \%$ of the internationally imported cases where the top three contributors are: Shanghai 
(28.1\%), Beijing (14\%), and Shenzhen (12.8\%). In terms of relative risk of importation, the countries at higher risk of importation after the implementation of the Wuhan travel ban are: Japan (11\% pre-travel ban, $13.9 \%$ post-travel ban), Thailand (22.8\% pre-travel ban, $13 \%$ post-travel ban), Republic of Korea (7.4\% pre-travel ban, $11.3 \%$ post-travel ban), Taiwan (9.5\% pre-travel ban, $10 \%$ post-travel ban), and USA (4.7\% pre-travel ban, $5.7 \%$ post-travel ban).

\section{International travel restrictions and transmissibility reduction}

Starting early February 2020, 59 airline companies suspended or limited flights to Mainland China and several countries including USA, Russia, Australia, and Italy have also imposed government issued travel restrictions (29-34). It is difficult to calculate exactly the level of traffic reduction imposed by these measures. For this reason, we analyze here two major scenarios in which international travel restrictions produce a $40 \%$ and $90 \%$ overall traffic reduction to and from Mainland China. A relative reduction of transmissibility could be achieved through early detection and isolation of cases, as well as behavioral changes and awareness of the disease in the population. Along with travel reductions, we consider three scenarios concerning disease transmissibility: i) a status quo situation with the same transmissibility found from the model calibration through 23 January 2020; ii) a moderate relative reduction of the original transmissibility $(25 \%)$, corresponding to a transmissibility dampening factor of $r=0.75$; and iii) a strong reduction (50\%) of the original transmissibility $(r=0.50)$. In Fig. 4 we show the combined effects of the travel and transmissibility reductions on the epidemic incidence in Mainland China and the number of exported cases to other countries.

The simulated scenarios show that even in the case of $90 \%$ travel reductions (Fig. 4D), if transmissibility is not reduced $(r=1)$, the epidemic in Mainland China is delayed for no more than 2 weeks. The model projects that in the status quo scenario the peak of the epidemic in Mainland China is reached at the end of April - early May 2020. It is worth remarking that the epidemic peak in Wuhan in the absence of transmissibility reductions would fall in the first week of March 2020. The number of cases imported in other countries (Fig. 4, A to C) is initially affected by a tenfold reduction, but by 1 March 2020 when there is no transmissibility reduction $(r=1)$, this number has reached again the levels of 170 and 35 detected cases per day for the $40 \%$ and $90 \%$ travel restrictions scenarios, respectively. The concurrent presence of both travel and transmissibility reductions, however, produce a much larger synergistic effect visible by both delaying the epidemic activity in Mainland China and the number of internationally imported cases. In the moderate transmissibility reduction scenarios $(r=0.75)$ the epidemic peak is delayed to late June 2020 and the total number of international case importations by 1 March 2020 are 26 and 5 detected cases per day for the $40 \%$ and $90 \%$ travel restrictions scenarios, respectively. Even larger travel limitations ( $>90 \%)$ will extend the period of time during which the importation of cases is greatly reduced. The strong transmissibility reduction $(r=0.5)$ along with travel restrictions does delay the epidemic growth in Mainland China that never surpasses the daily incidence of 1 case per 1,000 in Mainland China, and the number of imported cases at international destinations are always in the single digit range. The effect of the transmissibility reduction is visible also on the short term epidemic curve in Mainland China as shown in Fig. 1A, with a drastic reduction of the growth of the number of cases by 22 February 2020 with respect to the status quo epidemic curve. In Fig. 1C, we also report the estimated number of detected international importations estimated by the model in the strong transmissibility reduction scenario. The results are in good agreement with the data collected from the travel history of international imported cases after 23 January 2020 $(16,17)$. Similar results are obtained also by assuming that the transmissibility reduction interventions are successful in bringing the reproductive number below the epidemic threshold in the second half of February as data from Mainland China seems to suggest (28).

Finally, it is worth remarking that a large number of imported infected individuals from Mainland China were undetected and have been potentially dispersed to international locations. By 1 February 2020 in the strong transmissibility reduction scenario the model estimates 101 [90\% CI 50-173] importation events with one or more potential cases that could be seeding multiple epidemic outbreaks across the world, thus potentially leading to the international expansion of the COVID-19 epidemic. This finding is consistent with the emergence of COVID-19 outbreaks in countries across the world, including Italy, Republic of South Korea and Iran in the second half of February 2020.

Our analysis, as with all modeling exercises, has several limitations and assumptions to consider. The model parameters such as generation time and incubation period are chosen based on early results on the COVID-19 outbreak and prior knowledge of SARS and MERS coronavirus epidemiology. While the model is stable to variations in these parameters, more information on the key characteristic of the disease would considerably reduce uncertainties. The transmission and mobility model does not account, at this stage, for heterogeneities due to age differences in susceptibility and contact patterns. The calibration of the model does not consider correlations among importations (family travel) and assumes that travel probabilities are homogeneous across all individuals in the catchment area of each transportation hub. We were not able to find reliable data sources on the effectiveness 
of containment measures in place in Mainland China before 23 January (e.g., body temperature screening for departure in Wuhan International airport) which are thus not included in the model. In the travel restriction scenario we assume long term enforcement of individual mobility restrictions (travel was restricted until the end of June 2020). This might not be a feasible nor sustainable policy for such a long period of time.

\section{Discussion}

The analysis of the COVID-19 outbreak and the modeling assessment of the effects of travel limitations could be instrumental to national and international agencies for public health response planning. We show that by 23 January 2020, the epidemic had already spread to other cities within Mainland China. The travel quarantine around Wuhan has only modestly delayed the epidemic spread to other areas of Mainland China. This is in agreement with separate studies on the diffusion of the SARS-CoV-2 virus in Mainland China (27, 35, 36). The model indicates that while the Wuhan travel ban was initially effective at reducing international case importations, the number of cases observed outside Mainland China will resume its growth after 2-3 weeks from cases that originated elsewhere. Furthermore, the modeling study shows that additional travel limitations up to $90 \%$ of the traffic have a modest effect unless paired with public health interventions and behavioral changes that achieve a considerable reduction in the disease transmissibility (37). The model also indicates that even in the presence of the strong travel restrictions in place to and from Mainland China since 23 January 2020, a large number of individuals exposed to the SARS-CoV-2 have been traveling internationally without being detected. Moving forward we expect that travel restrictions to COVID-19 affected areas will have modest effects, and that transmission-reduction interventions will provide the greatest benefit to mitigate the epidemic. The above results provides data with potential uses for the definition of optimized containment schemes and mitigation policies that includes the local and international dimension of the COVID-19 epidemic.

\section{REFERENCES AND NOTES}

1. World Health Organization, "Novel Coronavirus - China" (WHO, 2020); www. who.int/csr/don/12-january-2020-novel-coronavirus-china/en/.

2. The Center for Systems Science and Engineering, Johns Hopkins, "Coronavirus COVID-19 Global Cases" (2020); www.arcgis.com/apps/opsdashboard/index.html\#/bda7594740fd402994234 67b48e9ecf6.

3. World Health Organization, "Novel Coronavirus - Situation Report 43" (WHO, 2020); $\quad$ www.who.int/docs/default-source/coronaviruse/situationreports/20200303-sitrep-43-covid-19.pdf?sfvrsn=2c21c09c 2.

4. D. Balcan, V. Colizza, B. Gonçalves, H. Hu, J. J. Ramasco, A. Vespignani, Multiscale mobility networks and the spatial spreading of infectious diseases. Proc. Natl. Acad. Sci. U.S.A. 106, 21484-21489 (2009). doi:10.1073/pnas.0906910106 Medline

5. D. Balcan, B. Gonçalves, H. Hu, J. J. Ramasco, V. Colizza, A. Vespignani, Modeling the spatial spread of infectious diseases: The GLobal Epidemic and Mobility computational model. J. Comput. Sci. 1, $132-145$ (2010). doi:10.1016/j.jocs.2010.07.002 Medline

6. M. F. Gomes, A. Pastore Y Piontti, L. Rossi, D. Chao, I. Longini, M. E. Halloran, A. Vespignani, Assessing the international spreading risk associated with the 2014 west african ebola outbreak. PLOS Curr. 10.1371/currents.outbreaks.cd818f63d40e24aef769dda7df9e0da5 (2014). doi:10.1371/currents. outbreaks.cd818f63d40e24aef769dda7df9e0da5 Medline

7. Q. Zhang, K. Sun, M. Chinazzi, A. Pastore Y Piontti, N. E. Dean, D. P. Rojas, S. Merler, D. Mistry, P. Poletti, L. Rossi, M. Bray, M. E. Halloran, I. M. Longini Jr., A. Vespignani, Spread of Zika virus in the Americas. Proc. Natl. Acad. Sci. U.S.A. 114, E4334-E4343 (2017). doi:10.1073/pnas.1620161114 Medline

8. A. Rambaut, "Preliminary phylogenetic analysis of 11 nCoV2019 genomes, 202001-19" (2020); http://virological.org/t/preliminary-phylogenetic-analysis-of-11ncov2019-genomes-2020-01-19/329.

9. N. Imai, A. Cori, I. Dorigatti, M. Baguelin, C. A. Donnelly, S. Riley, N. M. Ferguson, "Report 3: Transmissibility of 2019-nCoV" (2020) www.imperial.ac.uk/mrcglobal-infectious-disease-analysis/news--wuhan-coronavirus/.

10. K. Anderson, "Estimates of the clock and TMRCA for 2019-nCoV based on 27 genomes" (2020); http://virological.org/t/clock-and-tmrca-based-on-27genomes/347.

11. T. Bedford, R. Neher, J. Hadfield, E. Hodcroft, M. Ilcisin, N. Müller, "Genomic analysis of nCoV spread. Situation report 2020-01-23" (2020); https:/nextstrain.org/narratives/ncov/sit-rep/2020-01-23.

12. See supplementary materials.

13. M. Sunnåker, A. G. Busetto, E. Numminen, J. Corander, M. Foll, C. Dessimoz, Approximate Bayesian computation. PLOS Comput. Biol. 9, e1002803 (2013). doi:10.1371/journal.pcbi.1002803 Medline

14. R. Niehus, P. M. De Salazar, A. Taylor, M. Lipsitch, Quantifying bias of COVID-19 prevalence and severity estimates in Wuhan, China that depend on reported cases in international travelers. www.medrxiv.org/content/10.1101/2020.02.13.20022707v2 (2020).

15. P. M. De Salazar, R. Niehus, A. Taylor, C. O. Buckee, M. Lipsitch, Using predicted imports of 2019-nCoV cases to determine locations that may not be identifying all imported cases. www.medrxiv.org/content/10.1101/2020.02.04.20020495v2 (2020).

16. K. Sun, J. Chen, C. Viboud, Early epidemiological analysis of the coronavirus disease 2019 outbreak based on crowdsourced data: a population-level observational study. Lancet Digital Health 10.1016/S2589-7500(20)30026-1 (2020). doi:10.1016/S2589-7500(20)30026-1

17. F. Pinotti, L. Di Domenico, E. Ortega, M. Mancastroppa, G. Pullano, E. Valdano, P. Boelle, C. Poletto, V. Colizza, Lessons learnt from 288 COVID-19 international cases: importations over time, effect of interventions, underdetection of imported cases. www.medrxiv.org/content/10.1101/2020.02.24.20027326v1 (2020).

18. J. A. Backer, D. Klinkenberg, J. Wallinga, The incubation period of 2019-nCoV infections among travellers from Wuhan, China. www.medrxiv.org/content/early/2020/01/28/2020.01.27.20018986 (2020).

19. C. Huang, Y. Wang, X. Li, L. Ren, J. Zhao, Y. Hu, L. Zhang, G. Fan, J. Xu, X. Gu, Z. Cheng, T. Yu, J. Xia, Y. Wei, W. Wu, X. Xie, W. Yin, H. Li, M. Liu, Y. Xiao, H. Gao, L. Guo, J. Xie, G. Wang, R. Jiang, Z. Gao, Q. Jin, J. Wang, B. Cao, Clinical features of patients infected with 2019 novel coronavirus in Wuhan, China. Lancet 395, 497506 (2020). doi:10.1016/S0140-6736(20)30183-5 Medline

20. Q. Li, X. Guan, P. Wu, X. Wang, L. Zhou, Y. Tong, R. Ren, K. S. M. Leung, E. H. Y. Lau, J. Y. Wong, X. Xing, N. Xiang, Y. Wu, C. Li, Q. Chen, D. Li, T. Liu, J. Zhao, M. Li, W. Tu, C. Chen, L. Jin, R. Yang, Q. Wang, S. Zhou, R. Wang, H. Liu, Y. Luo, Y. Liu, G. Shao, H. Li, Z. Tao, Y. Yang, Z. Deng, B. Liu, Z. Ma, Y. Zhang, G. Shi, T. T. Y. Lam, J. T. K. Wu, G. F. Gao, B. J. Cowling, B. Yang, G. M. Leung, Z. Feng, Early transmission dynamics in Wuhan, China, of novel coronavirus-infected pneumonia. N. Engl. J. Med. 10.1056/NEJMoa2001316 (2020). doi:10.1056/NEJMoa2001316 Medline

21. M. Lipsitch, T. Cohen, B. Cooper, J. M. Robins, S. Ma, L. James, G. Gopalakrishna, S. K. Chew, C. C. Tan, M. H. Samore, D. Fisman, M. Murray, Transmission dynamics and control of severe acute respiratory syndrome. Science 300, 1966-1970 (2003). doi:10.1126/science.1086616 Medline

22. S. Riley, C. Fraser, C. A. Donnelly, A. C. Ghani, L. J. Abu-Raddad, A. J. Hedley, G. M. Leung, L. Ho, T. Lam, T. Q. Thach, P. Chau, K. P. Chan, S. V. Lo, P. Y. Leung, T. Tsang, W. Ho, K. H. Lee, E. M. Lau, N. M. Ferguson, R. M. Anderson, Transmission 
dynamics of the etiological agent of SARS in Hong Kong: Impact of public health intervention. Science 300, 1961-1966 (2003). doi:10.1126/science.1086478 Medline

23. M. Kraemer, D. Pigott, “Epidemiological Data from the nCoV-2019 Outbreak: Early Descriptions from Publicly Available Data" (2020); http:/virological.org/t/epidemiological-data-from-the-ncov-2019-outbreakearly-descriptions-from-publicly-available-data/337.

24. J. Riou, C. L. Althaus, Pattern of early human-to-human transmission of Wuhan 2019 novel coronavirus (2019-nCoV), December 2019 to January 2020. Euro Surveill. 25, 4 (2020). doi:10.2807/1560-7917.ES.2020.25.4.2000058 Medline

25. S. Zhao, Q. Lin, J. Ran, S. S. Musa, G. Yang, W. Wang, Y. Lou, D. Gao, L. Yang, D. He, M. H. Wang, Preliminary estimation of the basic reproduction number of novel coronavirus (2019-nCoV) in China, from 2019 to 2020: A data-driven analysis in the early phase of the outbreak. Int. J. Infect. Dis. 92, 214-217 (2020). doi:10.1016/i.iiid.2020.01.050 Medline

26. J. M. Read et al., Novel coronavirus 2019-nCov: early estimation of epidemiological parameters and epidemic predictions. www.medrxiv.org/content/10.1101/2020.01.23.20018549v2 (2020).

27. $\mathrm{H}$. Tian et al., Early evaluation of transmission control measures in response to the 2019 novel coronavirus outbreak in China. www.medrxiv.org/content/10.1101/2020.01.30.20019844v3 (2020).

28. World Health Organization, "Novel Coronavirus - Situation Report 12" (WHO, 2020); www.who.int/docs/default-source/coronaviruse/situationreports/20200201-sitrep-12-ncov.pdf?sfvrsn=273c5d35 2.

29. New York Times, "North Korea Bans Foreign Tourists Over Coronavirus, Tour Operator Says" (NYT, 2020); www.nytimes.com/2020/01/21/world/asia/coronavirus-china-north-koreatourism-ban.html.

30. Channel News Asia, "Scoot cancels flights to China's Wuhan over virus outbreak", (CNA, 2020); www.channelnewsasia.com/news/singapore/wuhan-virus-scootcancels-flights-mtr-train-12309076.

31. Toui tre News, "Vietnam aviation authority ceases all flights to and from coronavirus-stricken Wuhan" (2020); https://tuoitrenews.vn/news/business/20200124/vietnam-aviation-authorityceases-all-flights-to-and-from-coronavirusstricken-wuhan/52707.html.

32. Reuters, "Russia ramps up controls, shuts China border crossings over virus fears" (2020) www.reuters.com/article/us-china-health-russia-border/russianregions-in-far-east-close-border-with-china-amid-coronavirus-fears-tassidUSKBN1ZROTU.

33. Center for Disease Control, "Novel Coronavirus in China" (CDC, 2020): https://wwwnc.cdc.gov/travel/notices/warning/novel-coronavirus-china.

34. The Australian, "Travelers from China to be denied entry to Australia" (2020); www.theaustralian.com.au/nation/travellers-from-china-to-be-denied-entryinto-australia/news-story/7b7619d44af78dd7395a934e22b52997.

35. J. T. Wu, K. Leung, G. M. Leung, Nowcasting and forecasting the potential domestic and international spread of the 2019-nCoV outbreak originating in Wuhan, China: A modelling study. Lancet 395, 689-697 (2020). doi:10.1016/S01406736(20)30260-9 Medline

36. Z. Du, L. Wang, S. Cauchemez, X. Xu, X. Wang, B. J. Cowling, L. A. Meyers, Risk for Transportation of 2019 Novel Coronavirus Disease from Wuhan to Other Cities in China. Emerg. Infect. Dis. 10.3201/eid2605.200146 (2020). doi:10.3201/eid2605.200146 Medline

37. J. M. Drake, S. K. Chew, S. Ma, Societal learning in epidemics: Intervention effectiveness during the 2003 SARS outbreak in Singapore. PLOS ONE 1, e20 (2006). doi:10.1371/journal.pone.0000020 Medline

38. D. Balcan, H. Hu, B. Goncalves, P. Bajardi, C. Poletto, J. J. Ramasco, D. Paolotti, N. Perra, M. Tizzoni, W. Van den Broeck, V. Colizza, A. Vespignani, Seasonal transmission potential and activity peaks of the new influenza A(H1N1): A Monte Carlo likelihood analysis based on human mobility. BMC Med. 7, 45 (2009). doi:10.1186/1741-7015-7-45 Medline

39. Data are available from Baidu Qianxi platform (http://qianxi.baidu.com/), operated by Baidu Inc.

40. The Economic Times, "Nepal confirms first case of deadly coronavirus" (24 January https:/economictimes.indiatimes.com/news/international/world-news/nepal- confirms-first-case-of-deadly-coronavirus/articleshow/73590302.cms

41. The Guardian, "Coronavirus: three cases in NSW and one in Victoria as infection reaches Australia" (25 January 2020): www.theguardian.com/science/2020/jan/25/coronavirus-five-people-in-nswbeing-tested-for-deadly-disease.

42. WHO, "Novel Coronavirus - Japan (ex-China)" (17 January 2020); www.who.int/csr/don/17-january-2020-novel-coronavirus-japan-ex-china/en/.

43. WHO, "Novel Coronavirus - Thailand (ex-China)" (14 January 2020); www.who.int/csr/don/14-january-2020-novel-coronavirus-thailand-exchina/en/.

44. Taiwan News, "Taiwan reports 9th case of Wuhan coronavirus" (30 January 2020); www.taiwannews.com.tw/en/news/3867321

45. Nippon.com, "New Coronavirus Cases in Japan Rise to 14" (31 January 2020); www.nippon.com/en/news/yii2020013100070/new-coronavirus-cases-injapan-rise-to-14.html.

46. Bureau of Information Ministry of Public Health Office Thailand, "Ministry of Public Health receives 2 tourists from Wuhan for pneumonia at Bamrasnaradura Institute" (17 January 2020); https://pr.moph.go.th/?url=pr/detail/2/04/137232/.

47. Business Insider, "A 2nd case of the Wuhan coronavirus in the US was just confirmed in Chicago" (24 January 2020); www.businessinsider.fr/us/wuhancoronavirus-second-confirmed-case-in-the-us-chicago-2020-1.

48. Xinhuanet, "Two new cases of pneumonitis infected with coronavirus confirmed in Vietnam" (24 January 2020); www.xinhuanet.com/world/202001/24/c 1125498544.htm.

49. CDC, "First Travel-related Case of 2019 Novel Coronavirus Detected in United States" (21 January 2020); www.cdc.gov/media/releases/2020/p0121-novelcoronavirus-travel-case.html.

50. VnExpress, "The 7th case in Vietnam is infected with corona virus" (2 February 2020); https://vnexpress.net/suc-khoe/ca-thu-7-0-viet-nam-nhiem-viruscorona-4049017.html.

51. The National, "Coronavirus: UAE records first case" (29 January 2020); www.thenational.ae/uae/health/coronavirus-uae-records-first-case-1.971253.

52. Reuters, "France confirms fourth case of coronavirus in elderly Chinese tourist" (28 January 2020); www.reuters.com/article/us-china-health-france/franceconfirms-fourth-case-of-coronavirus-in-elderly-chinese-touristidUSKBN1ZR2CM.

53. CNA, "Novel coronavirus: Malaysia confirms 1 more case, Wuhan woman was in Singapore with family" (7 February 2020); www.channelnewsasia.com/news/asia/malaysia-wuhan-coronavirus-chinesenational-singapore-15-cases12405142 ?cid=h3 referral inarticlelinks 24082018 cna

54. VnExpress, "Three Vietnamese pneumonia have exposed many people" (30 January 2020); https://vnexpress,net/dich-viem-phoi-corona/ba-nguoi-vietviem-phoi-da-tiep-xuc-nhieu-nguoi-4048068.html.

55. The Japan Times, "Japan confirms third case of new coronavirus infection" (25 January 2020); www.japantimes.co.jp/news/2020/01/25/national/japanconfirms-third-case-new-coronavirus/\#.XI2Zm5NKilR.

56. New Strait Times, "Malaysia coronavirus cases rise to 10, including local man" (4 February 2020); www.nst.com.my/news/nation/2020/02/562509/malaysiacoronavirus-cases-rise-10-including-local-man.

57. Ministry of Health Singapore, "Fifth Confirmed Imported Case of Wuhan Coronavirus Infection in Singapore" (27 January 2020); www.moh.gov.sg/newshighlights/details/fifth-confirmed-imported-case-of-wuhan-coronavirusinfection-in-singapore-27Jan.

58. HUFFPOST, "Coronavirus in Paris and Bordeaux: what we know about the three cases" (25 January 2020); www.huffingtonpost.fr/entry/coronavirus-france-ceque-lon-sait fr $5 \mathrm{e} 2 \mathrm{bee00c5b67d8874b21f80.}$

59. 7NEWS, "Monash Medical Centre treating first Australian case of coronavirus" (24 January 2020); https://7news.com.au/news/health/first-australiancoronavirus-case-confirmed-in-victoria-c-664530.

60. Ministry of Health, Labor and Welfare, "About outbreak of patient of pneumonia associated with new type coronavirus (the second case)" (24 January 2020); www.mhlw.go.jp/stf/newpage 09079.html.

61. WHO, "Novel Coronavirus - Republic of Korea (ex-China)" (21 January 2020); 
www.who.int/csr/don/21-ianuary-2020-novel-coronavirus-republic-of-koreaex-china/en/.

62. Reuters, "Sri Lanka confirms first case of coronavirus: health official" (27 January 2020); www.reuters.com/article/us-health-china-sri-lanka/sri-lanka-confirmsfirst-case-of-coronavirus-health-official-idUSKBN1ZQ1WE.

63. CNA, "Wuhan virus: Singapore confirms 2 new cases, bringing total number infected to 7" (28 January 2020); www.channelnewsasia.com/news/singapore/wuhan-virus-singapore-latestconfirmed-cases-coronavirus-12360924.

64. CNA, "Singapore confirms 3 new cases of Wuhan virus; total of 10 infected" (29 January 2020); www.channelnewsasia.com/news/singapore/wuhan-virussingapore-new-confirmed-cases-10-total-12364556.

65. Bureau of Information Ministry of Public Health Office Thailand, "Ministry of Public Health raises surveillance levels for new species of coronary viruses during the Chinese New Year festival" (22 January 2020); https://pr.moph.go.th/?url=pr/detail/2/04/137484/.

66. The Pattaya News, "Thai Authorities confirm sixth case of Coronavirus found in Thailand in city of Hua Hin" (25 January 2020); https://thepattayanews.com/2020/01/25/thai-authorities-confirm-sixth-caseof-coronavirus-found-in-thailand-in-city-of-hua-hin/.

67. Ministry of Health, Labor and Welfare, "Outbreak of pneumonia patient related to new coronavirus (fifth case)" (28 January 2020); www.mhlw.go.jp/stf/newpage_09154.html.

68. Ministry of Health, Labor and Welfare, "About outbreak of patient of pneumonia associated with new coronavirus (the eighth case)" (29 January 2020); www.mhlw.go.jp/stf/newpage_09201.html.

69. The Korea Herald, "S. Korea reports 3rd confirmed case of Wuhan coronavirus" (26 January 2020); www.koreaherald.com/view.php?ud=20200126000024.

70. The Korea Herald, "S. Korea ups coronavirus alert, 4th case confirmed" (27 January 2020); www. koreaherald.com/view.php?ud=20200127000114.

71. KCDC, "The updates on novel Coronavirus infection in Korea" (2 February 2020); www.cdc.go. $\mathrm{kr} / \mathrm{board} /$ board.es?mid=a30402000000 bid=0030.

72. Malay Mail, "Health Ministry confirms three cases of coronavirus infection in Malaysia" (25 January 2020); www.malaymail.com/news/malaysia/2020/01/25/health-ministry-confirmsthree-cases-of-coronavirus-infection-in-malaysia/1831344.

73. CNA, "Cleared for discharge: What we know about the coronavirus patients who recovered in Malaysia" (11 February 2020); www.channelnewsasia.com/news/asia/wuhan-coronavirus-malaysiadischarged-patients-chinese-nationals-12417750.

74. CNN, "Philippines reports third confirmed case of novel coronavirus" (5 February 2020); www.cnnphilippines.com/news/2020/2/5/third-novel-coronaviruscase-Philippines.html.

75. CNA, "Singapore confirms first case of Wuhan virus" (23 January 2020); www.channelnewsasia.com/news/singapore/wuhan-virus-pneumoniasingapore-confirms-first-case- 12312860.

76. CNA, "Singapore confirms 3 new cases of Wuhan virus; total of 10 infected" (29 January 2020); www.channelnewsasia.com/news/singapore/wuhan-virussingapore-new-confirmed-cases-10-total-12364556.

77. ABC News, "Health authorities in Victoria and Queensland confirm more cases of coronavirus" (29 January 2020); www.abc.net.au/news/2020-01-29/victoriaconfirms-second-case-of-coronavirus/11911076.

78. Ministry of Health, Labor and Welfare, "About outbreak of patient of pneumonia related to new type coronavirus (the seventh case)" (28 January 2020); www.mhlw.go.jp/stf/newpage 09158.html.

79. Ministry of Health, Labor and Welfare, "Outbreak of pneumonia related to new type of coronavirus (17 cases)" (4 February 2020); www.mhlw.go.jp/stf/newpage 09310.html.

80. ABS-CBN News, "Philippines confirms first case of new coronavirus" (30 January 2020); https://news.abs-cbn.com/news/01/30/20/philippines-confirms-firstcase-of-new-coronavirus.

81. Ministry of Health Singapore, "Two More Cases of Confirmed Imported Case of Novel Coronavirus Infection in Singapore" (24 January 2020); www.moh.gov.sg/news-highlights/details/two-more-cases-of-confirmedimported-case-of-novel-coronavirus-infection-in-singapore.
82. The Online Citizen, "Three more confirmed cases of Wuhan virus; 13 confirmed cases in Singapore so far" (30 January 2020); www.theonlinecitizen.com/2020/01/30/three-more-confirmed-cases-ofwuhan-virus-13-confirmed-cases-in-singapore-so-far/.

83. Bureau of Information Ministry of Public Health Office Thailand, "Visiting tourists demonstration from Wuhan Corona virus no.5 at Rajavithi Hospital" (24 January 2020); https://pr.moph.go.th/?url=pr/detail/2/04/137685/.

84. News.Com.Au, "Fifth case of coronavirus confirmed in Australia as 10 people are investigated" (27 January 2020); www.news.com.au/world/asia/young-femalechinese-student-likely-to-be-fifth-case-in-australia-to-contractcoronavirus/news-story/f42f2e520b4a757cf748c7fba1617cba.

85. 7NEWS, "Coronavirus: First case confirmed in Queensland, bringing total in Australia to 7" (29 January 2020); https://7news.com.au/lifestyle/healthwellbeing/coronavirus-first-case-confirmed-in-queensland-bringing-total-inaustralia-to-7-c-671143.

86. Reuters, "Canada identifies first case of coronavirus" (25 January 2020); www.reuters.com/article/us-china-health-canada/canada-identifies-first-caseof-coronavirus-idUSKBN1Z00T9.

87. HUFFPOST, "Coronavirus in Paris and Bordeaux: what we know about the three cases" (25 January 2020); www.huffingtonpost.fr/entry/coronavirus-france-ceque-lon-sait fr 5e2bee00c5b67d8874b21f80.

88. The Mainichi Newspapers, "Japan confirms 4th case of new coronavirus infection" (26 January 2020) https://mainichi.jp/english/articles/20200126/p2g/00m/0na/081000c.

89. Ministry of Health, Labor and Welfare, "About outbreak of patient of pneumonia associated with new type coronavirus (the twelfth case)" (30 January 2020); www.mhlw.go.jp/stf/newpage 09239.html.

90. South China Morning Post, "China coronavirus: new cases confirmed in Singapore, Japan, South Korea and Nepal" (24 January 2020); www.scmp.com/news/asia/east-asia/article/3047463/china-coronavirusjapan-confirms-second-case-health-ministry.

91. Reuters, "Malaysia confirms fourth case of coronavirus infection" (24 January 2020); www.reuters.com/article/us-china-health-malaysia/malaysia-confirmsfourth-case-of-coronavirus-infection-idUSKBN1Z0065.

92. The Straits Times, "Singapore confirms 4th case of Wuhan virus; patient from Wuhan stayed at Sentosa hotel" (26 January 2020); www.straitstimes.com/singapore/singapore-confirms-4th-case-of-wuhanvirus-patient-from-wuhan-stayed-at-sentosa-hotel.

93. Ministry of Health Singapore, "Three More Confirmed Imported Cases of Wuhan Coronavirus Infection in Singapore" (30 January 2020); www.moh.gov.sg/newshighlights/details/three-more-confirmed-imported-cases-of-wuhancoronavirus-infection-in-singapore-30 Jan.

94. Ministry of Health Singapore, "Three More Confirmed Imported Cases of Wuhan Coronavirus Infection in Singapore" (31 January 2020); www.moh.gov.sg/newshighlights/details/three-more-confirmed-imported-cases-of-wuhancoronavirus-infection-in-singapore-31-jan.

95. Ministry of Health Singapore, "Two More Confirmed Imported Cases of Novel Coronavirus Infection in Singapore" (1 February 2020); www.moh.gov.sg/newshighlights/details/two-more-confirmed-imported-cases-of-novel-coronavirusinfection-in-singapore.

96. Bavarian State Ministry of Health and Care, "Three other coronavirus cases in Bavaria - connection with the first case - Bavaria's Minister of Health Huml: around 40 people should be tested on Wednesday as a precaution" (28 January 2020); www.stmgp.bayern.de/presse/drei-weitere-coronavirus-faelle-in-bayernzusammenhang-mit-dem-ersten-fall-bayerns/.

97. Global News, "Woman in her 20s confirmed as 3rd case of coronavirus in Ontario" (31 January 2020); https://globalnews.ca/news/6489956/3rd-casecoronavirus-confirmed-ontario/.

98. Helsinki Times, "Finland's first coronavirus patient began to show symptoms three days ago" (30 January 2020); www.helsinkitimes.fi/finland/finlandnews/domestic/17272-finland-s-first-coronavirus-patient-began-to-showsymptoms-three-days-ago.html.

99. II Messaggero, "Coronavirus in Rome, Conte: (Two confirmed cases are Chinese tourists. No alarms). Air traffic to and from China closed" (30 January 2020); www.لilmessaggero.it/italia/coronavirus_italia_ultimissime_30_gennaio_2020- 
5018383.html.

100. VOA, "Cambodia Confirms First Coronavirus Case" (27 January 2020); www.voanews.com/science-health/coronavirus-outbreak/cambodia-confirmsfirst-coronavirus-case.

101. KCDC, "The update on novel Coronavirus infection: One more case has been confirmed in Korea" (31 January 2020): www.cdc.go.kr/board/board.es?mid=a30402000000 bid=0030 act=view list no $=365915 \mathrm{tag}=\mathrm{nPage}=1$.

102. KCDC, "The updates on the novel Coronavirus infection in Korea" (31 January 2020); www.cdc.go.kr/board/board.es?mid=a30402000000 bid=0030 act $=$ view list no $=365926$ tag $=n$ Page $=1$.

103. KCDC, "Four more cases of novel Coronavirus have been confirmed in Korea" (6 February 2020); $\quad$ www.cdc.go.kr/board/board.es?mid=a30402000000 bid $=0030$ act $=$ view list no $=366006$ tag $=n P a g e=1$.

104. CNA, "Wuhan virus: Singapore confirms 2 new cases, bringing total number infected to 7" (28 January 2020); www.channelnewsasia.com/news/singapore/wuhan-virus-singapore-latestconfirmed-cases-coronavirus-12360924

105. Business Insider, "The US has reported 9 coronavirus deaths among more than 120 cases. Here's what we know about the US patients.s" (2 March 2020); www.businessinsider.fr/us/wuhan-coronavirus-us-cases-health-risk-2020-1.

106. WLTZ First News, "Sweden Confirms First Coronavirus Case" (3 February 2020); www.wltz.com/2020/02/03/sweden-confirms-first-coronavirus-case/.

107. CDC, "CDC Confirms Seventh Case of 2019 Novel Coronavirus" (31 January 2020); $\quad$ www.cdc.gov/media/releases/2020/s0131-seventh-casecoronavirus.html.

108. Health.Vic, "Fourth novel coronavirus case in Victoria" (1 February 2020); www2.health.vic.gov.au/about/media-centre/MediaReleases/fourth-novelcoronavirus-case-victoria.

109. Sinchew, "19th confirmed diagnosis in Malaysia" (13 February 2020); www.sinchew.com.my/content/content 2216462.html.

110. Mass.gov, "Man returning from Wuhan, China is first case of 2019 Novel Coronavirus confirmed in Massachusetts" (1 February 2020); www.mass.gov/news/man-returning-from-wuhan-china-is-first-case-of-2019novel-coronavirus-confirmed-in.

111. Wisconsin Department of Health Services, "2019 Novel Coronavirus Case is Confirmed in Wisconsin" (5 February 2020); www.dhs. wisconsin.gov/news/releases/020520.htm.

112. From the Desk of the Director-General of Health Malaysia, "Kenyataan Akhbar KPK 10 Februari 2020 - Situasi Terkini Kejadian 2019-nCoV di Malaysia" (10 February 2020); https://kpkesihatan.com/2020/02/10/kenyataan-akhbarkpk-10-februari-2020-situasi-terkini-kejadian-2019-ncov-di-malaysia/.

\section{ACKNOWLEDGMENTS}

Funding: MEH acknowledges the support of the MIDAS-U54GM111274. SM and MA acknowledge support from the EU H2020 MOOD project. CG and LR acknowledge support from the EU H2O2O Icarus project. MC and AV acknowledge support from Google Cloud Healthcare and Solutions via GCP research credits program. The findings and conclusions in this study are those of the authors and do not necessarily represent the official position of the funding agencies, the National Institutes of Health or U.S. Department of Health and Human Services. Author contributions: M.C. and A.V. designed research; M.C., J.T.D., M.A., C.G., M.L., S.M., A.P.P., K.M., L.R., K.S., C.V, X.X., H.Y., M.E.H., I.M.L., and A.V. performed research; M.C., J.T.D., A.P.P., K.M. and A.V. analyzed data; and M.C., J.T.D., M.A., C.G., M.L., S.M., A.P.P, K.M., L.R., K.S., C.V., X.X., H.Y., M.E.H., I.M.L., and A.V. wrote and edited the paper. Competing interests: MEH reports grants from National Institute of General Medical Sciences, during the conduct of the study; AV reports grants and personal fees from Metabiota inc., outside the submitted work; MC and APyP report grants from Metabiota inc., outside the submitted work; $\mathrm{HY}$ reports grants from Glaxosmithkline (China) Investment Co., Ltd, grants from Yichang HEC Changjiang Pharmaceutical Co., Ltd, grants from Sanofi Pasteur, grants from Shanghai Roche Pharmaceuticals Company, outside the submitted work. No other relationships or activities that could appear to have influenced the submitted work. Data and materials availability: Proprietary airline data are commercially available from Official
Aviation Guide (OAG) and IATA databases. All other data that support the plots within this paper and other findings of this study are available at https:/github.com/mobs-lab/COVID-19/blob/master/README.md (DOI:10.5281/zenodo.3697201). The GLEAM model is publicly available at www.gleamviz.org/.

\section{SUPPLEMENTARY MATERIALS}

science.sciencemag.org/cgi/content/full/science.aba9757/DC1

Material and Methods

Figs. S1 and S2

Table S1

References (38-112)

MDAR Reproducibility Checklist

20 January 2020; resubmitted 7 February 2020

Accepted 5 March 2020

Published online 6 March 2020

10.1126/science.aba9757 

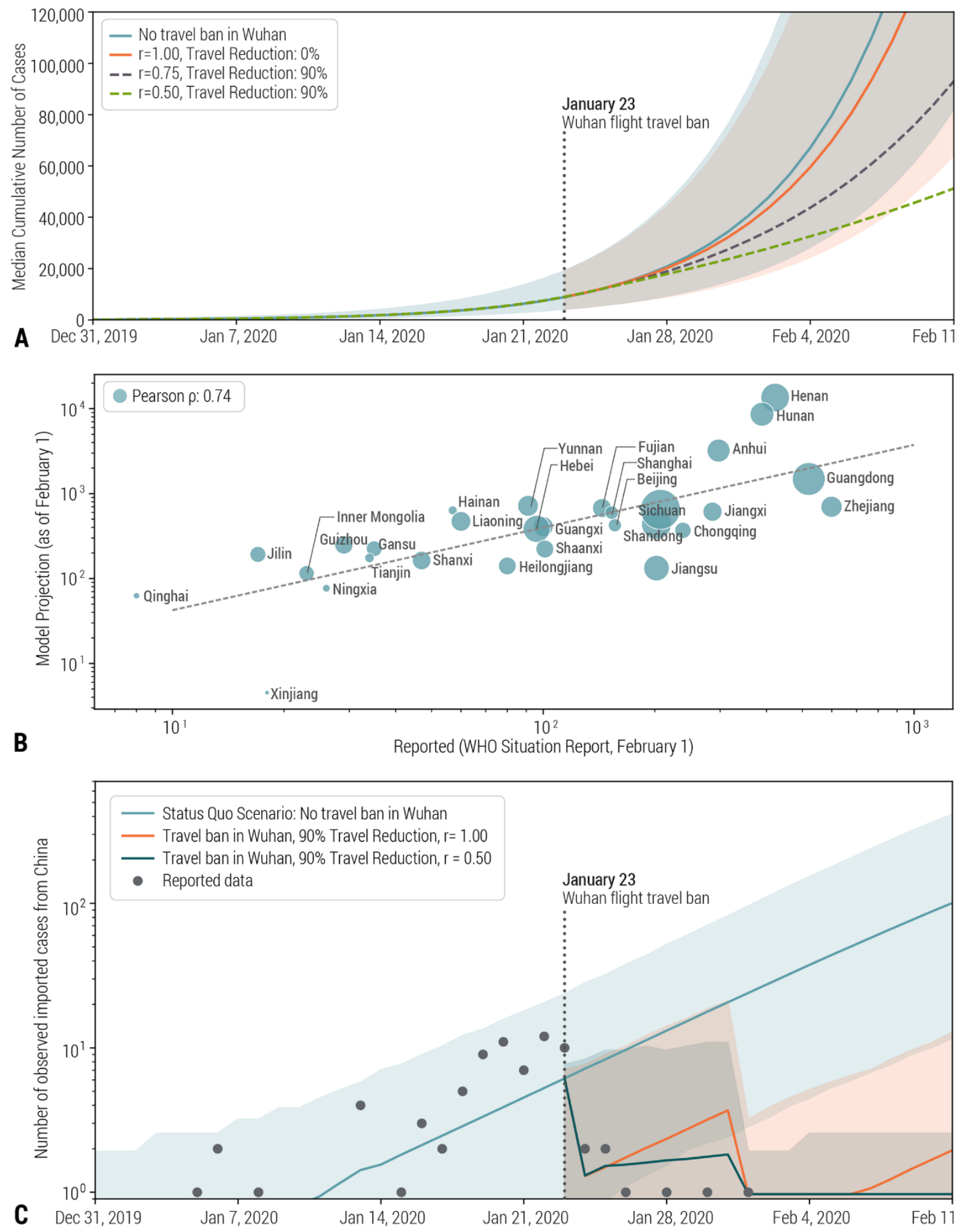

Fig. 1. Effect of the Wuhan travel ban on the COVID-19 epidemic. (A) Trajectory of the 2019-nCoV epidemic in Chinese locations (excluding Wuhan) under the travel ban to and from Wuhan in effect as of 23 January 2020. The lines represent the median cumulative number of cases while the shaded areas represent the $90 \%$ reference range. The figure includes also the scenarios with relative transmissibility reduction $r$, and international travel restrictions. (B) Correlation plot between the number of cases reported in each province by the WHO situation report and model projections on 1 February 2020. The size of the circles are proportional to the population size in each province. We note that no provinces were reporting zero cases by that date. (C) Projections of the average, detected number of daily international case importations for different modeling scenarios. Shaded areas represent the $99 \%$ reference range. We report the observed data of international case importations with a travel history from China by arrival date. We also report scenarios with relative transmissibility reduction $r$. Data points after 23 January 2020 are used as out of sample validation and not used in the model calibration. 

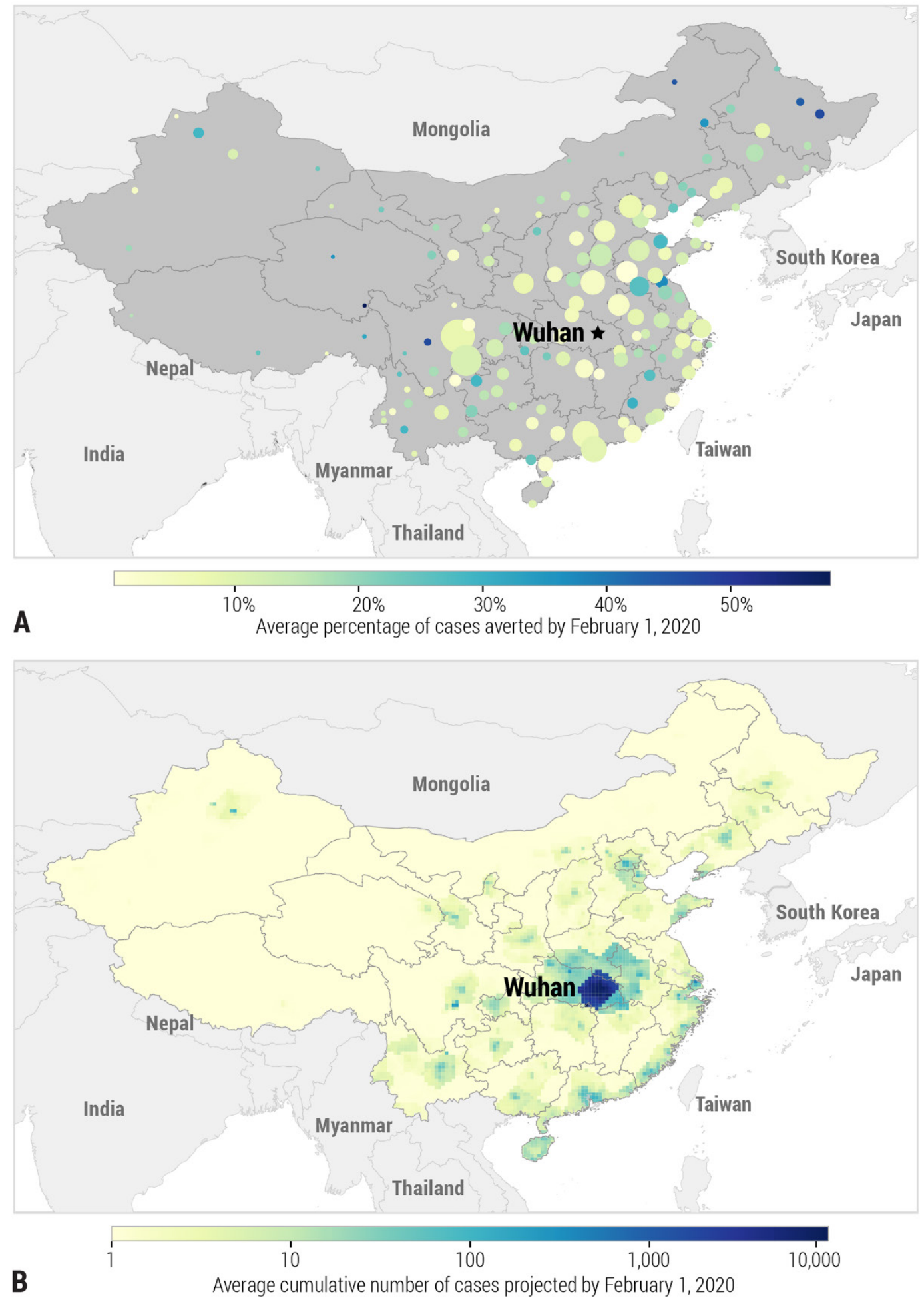

Fig. 2. Effects of Wuhan travel ban on COVID-19 incidence across Mainland China. (A) Relative incidence reduction as of 1 February 2020. The color of circles represents the relative reduction in the number of cases, while the size represents the population in the region. (B) Projected cumulative number of cases at the resolution of $0.25^{\circ} \times$ $0.25^{\circ}$ cells by the same date, after implementing travel restrictions in Wuhan. 
Case Importations
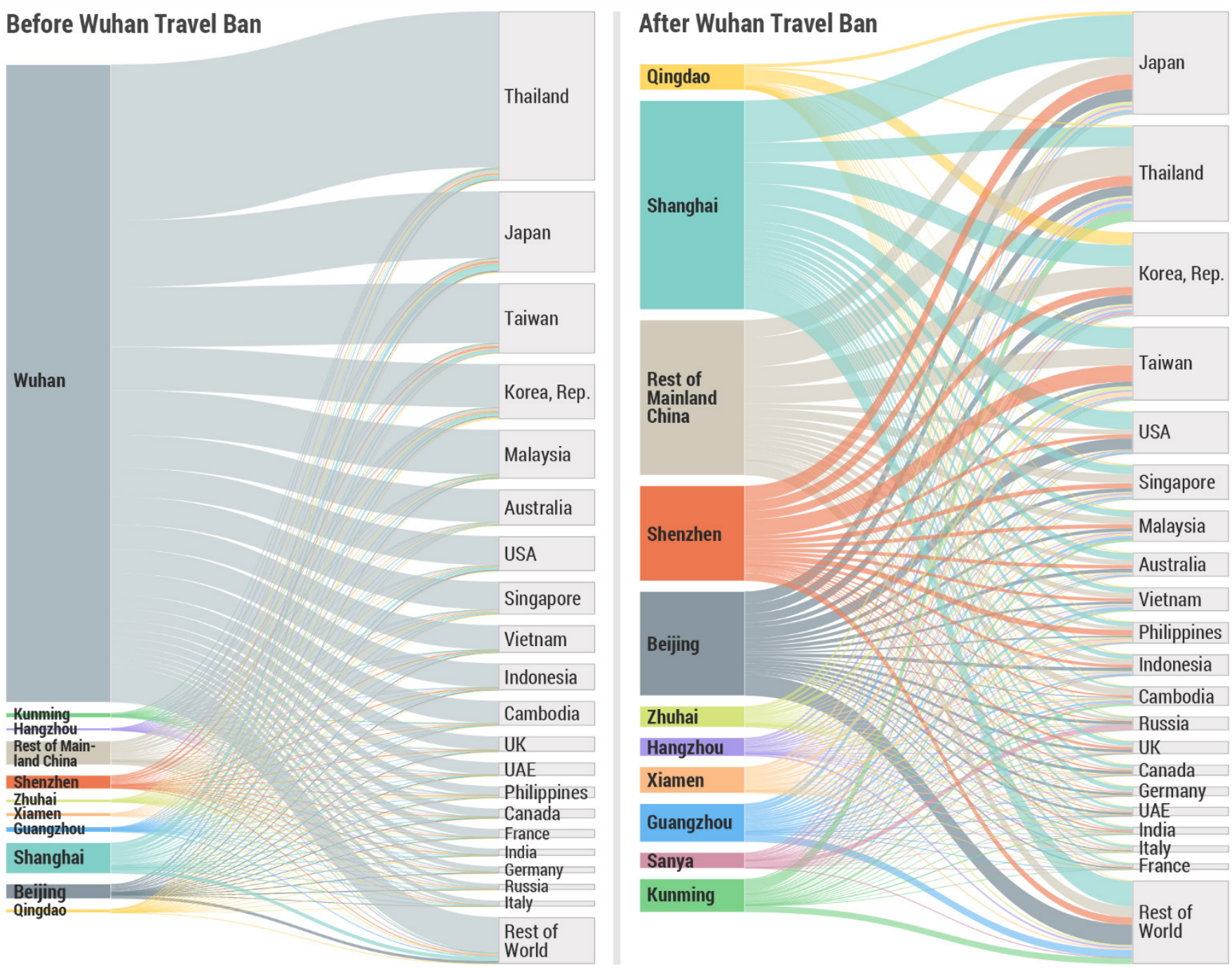

Fig. 3. Relative risk of case importation. Contribution to the relative risk of importation of the top 10 Chinese cities (plus the rest of Mainland China) until 22 January and after Wuhan travel ban from 23 January to 1 March 2020. The listed countries correspond to the top 20 countries at risk of importation. Flows are proportional to the relative probability that a single imported case will be traveling from a given origin to a specific destination. 

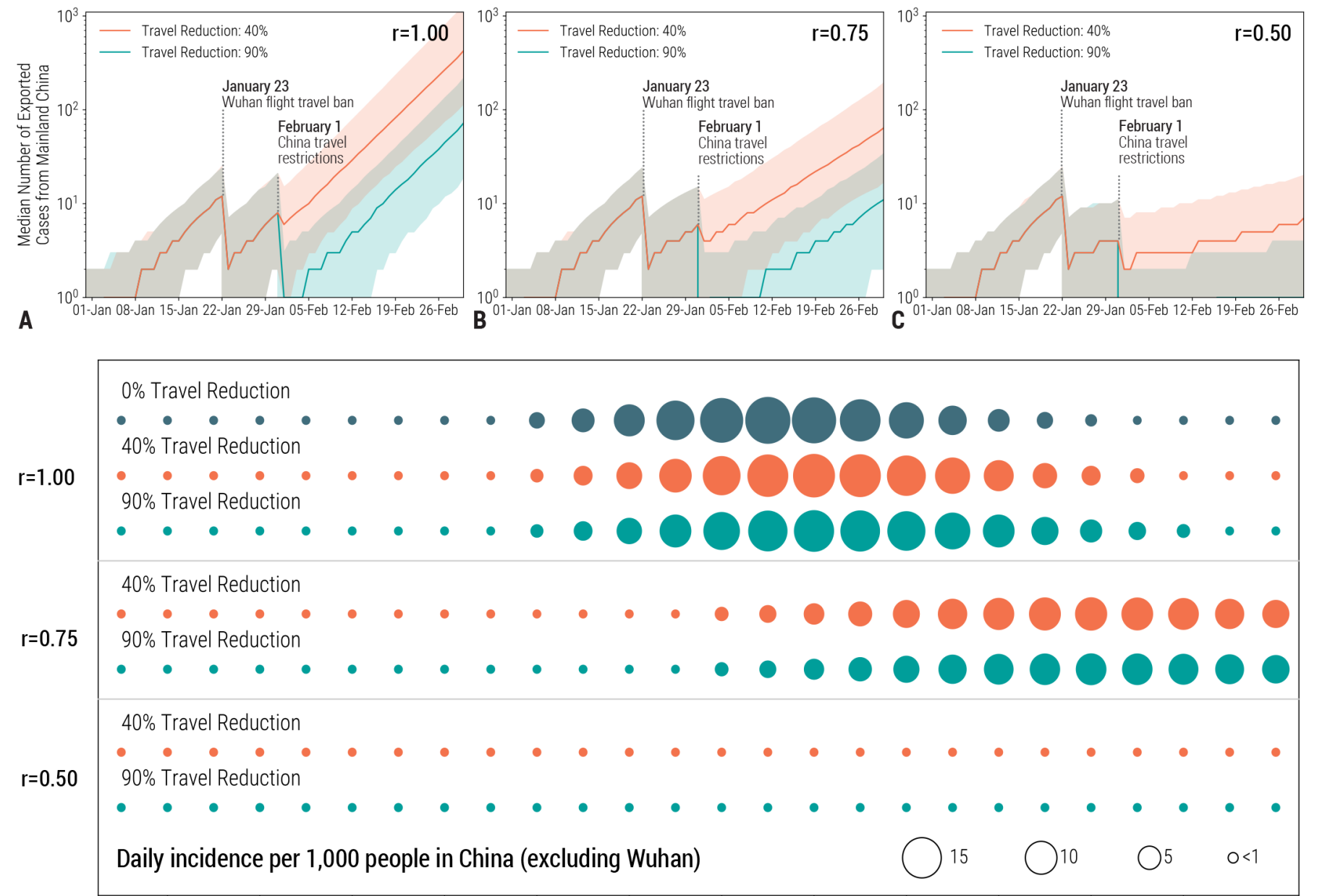

D

18-Jan $\quad$ 01-Feb 15-Feb 29-Feb 14-Mar 28-Mar 11-Apr 25-Apr 09 -May 23-May 06 -Jun 20-Jun

Fig. 4. Combined effects of travel and transmissibility reductions on the epidemic. (A) Median total number of imported cases from Mainland China with no transmissibility reduction, and travel reductions $\in\{40 \%, 90 \%\}$. (B) Same as (A) for the moderate transmissibility reduction scenario $(r=0.75)$. (C) Same as (A) for the strong transmissibility reduction scenario $(r=0.5)$. Shaded areas represent the $90 \%$ confidence interval. (D) Incidence in Mainland China excluding Wuhan for the different scenarios considered in (A) to (C). 